\title{
Improved Performance of ZnO/n-Si Solar Cells
}

\author{
Dr. Khalid Khaleel Mohamed
}

Electrical Engineering

M osul-University, Iraq

\begin{abstract}
This research is intended to improve the performance of $\mathrm{ZnO} / \mathrm{n}$-Si solar cells. The structures were fabricated using thermal evaporation techniques. The indium dopant at suitable heat treatment is used to enhance the electrical characteristics of $\mathrm{ZnO}$ layer resulting in reducing atmospheric condition to change the stiochiometry of $\mathrm{ZnO}$ layer. The electric properties of the fabricated samples are dependent on many parameters such as annealing temperature, $\mathrm{ZnO}$ layer thickness, Indium layer thickness and temperature. The indium layer were deposited at different thickness (10-30) nm during the fabrication of the $\mathrm{ZnO} / \mathrm{n}$-Si solar cells. The resultant samples has been studied and the results obtained show an improvement in the efficiency of $0.4 \%$ compared with the standard $\mathrm{ZnO} / \mathrm{n}-\mathrm{Si}$ solar cell.
\end{abstract}

Keyword: $\mathrm{ZnO} / \mathrm{n}-\mathrm{Si}$, Indium, Thermal Evaporation.
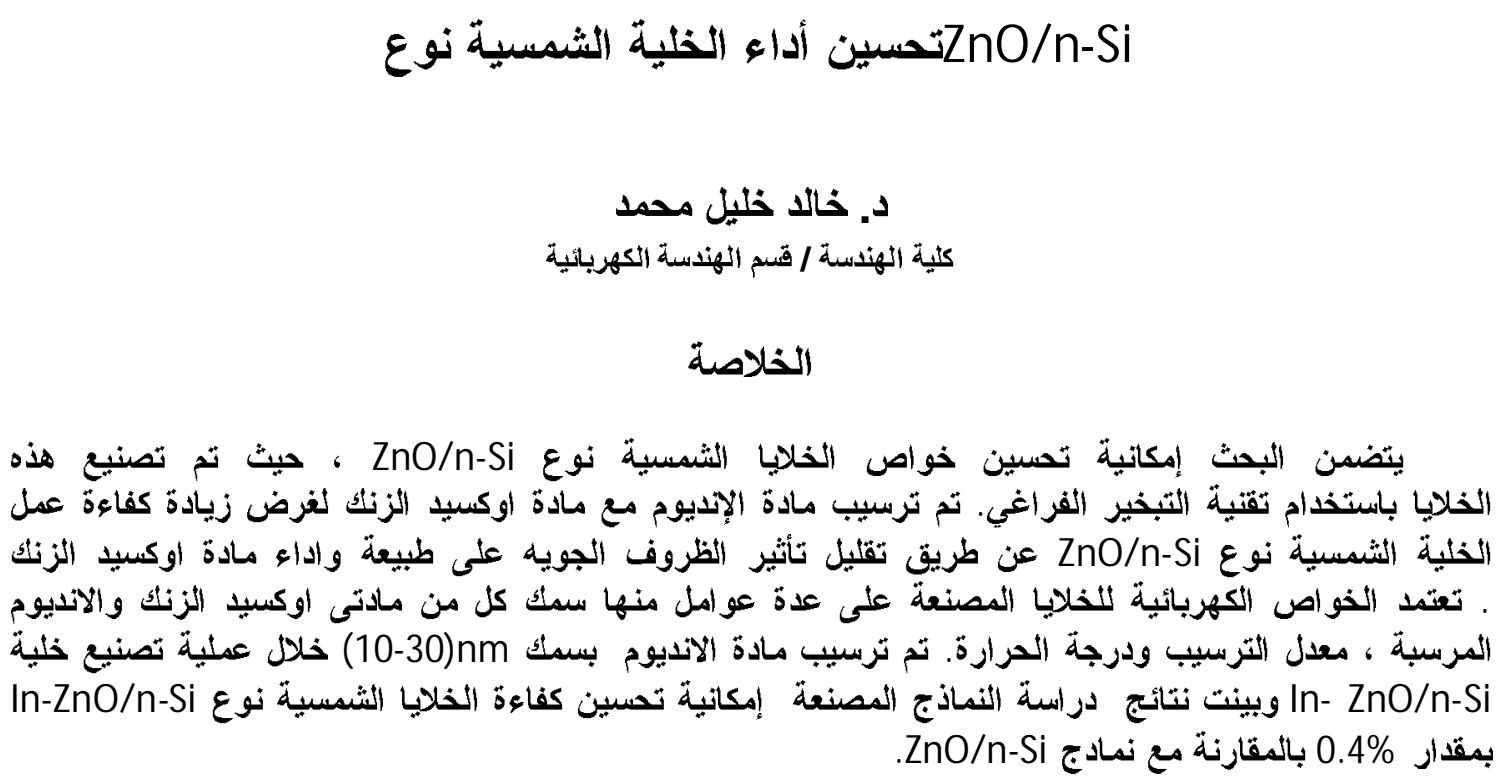


\section{1-Introduction:}

Compound semiconductor and their alloys are of considerable interest in the field of electronic and optoelectrical device. $\mathrm{ZnO}$ film is receiving increased attention for various microelectronic applications. It has potential uses in photo detectors, solar cells and light emitting diodes [1]. $\mathrm{ZnO}$ is a II-VI compound semiconductor with a wide direct band of 3.3 ev (at room temperature) and has a hexagonal quartzite structure with cell parameters of $\mathrm{a}=$ $0.325 \mathrm{~nm}, \mathrm{c}=0.5206 \mathrm{~nm}$ [2]. Zinc oxide has emerged as one of the most important window materials due to its large bandgap and used in photovoltaic especially in large area solar cells[ $3]$. The high production cost of the conventional solar cells require the search for cheaper methods suitable for solar energy conversion. $\mathrm{ZnO}$ thin film have been prepared by wide variety of techniques such as sputtering, evaporation, chemical vapor deposition (CVD) and spray pyrolsis [4].

The large excitation binding energy (60 mev) of $\mathrm{ZnO}$ leads to the existence and extreme growth of high-quality $\mathrm{ZnO}$ film on $\mathrm{Si}$. The main obstacles to get high-quality $\mathrm{ZnO}$ on $\mathrm{Si}$ are to overcome the large lattice mismatch and to avoid the amorphous $\mathrm{SiO}_{2}$ layer generated at the $\mathrm{Si}$ surface prior to or during $\mathrm{ZnO}$ growth, since $\mathrm{Si}$ can be easily oxidized in the oxygen environments [4]. To avoid these problems, some efforts have been made to use $\mathrm{ZnS}, \mathrm{Zn}$ metal layer, and nitridation of silicon surface [5].

In this paper $\mathrm{ZnO}$ films were deposited by thermal evaporation technique on the Si surface, followed by deposition of indium thin layer with variable thickness. Then a thin layer of indium tin oxide is deposited to suppress oxygen diffusion to $\mathrm{Si}$ wafer. The effect of $\mathrm{ZnO}$ layer thickness, indium layer thickness, annealing temperature, deposition rate are measured and analyzed.

\section{2-Experimental Work:}

The fabricated samples were prepared by vacuum evaporation technique using Balzer unit as a coating system. Phosphorus doped two-inch diameter monocrystalline n-Si wafers with thickness of $300 \mu \mathrm{m}$ and resistivity of about $4.5 \Omega \mathrm{cm}$, oriented in (100) plane were used. They were cut into relatively small segments $\left(4 \mathrm{~cm}^{2}\right)$ to be used as base semiconductor for the fabricated solar cells samples. The samples were cleaned with ethylalcohol to remove organic residues and then etched in buffered hydrofluoric acid for 2 minute to remove oxide films, then they were stored and protected from atmospheric contamination in vacuum desiccators.

A $\mathrm{ZnO}$ thin film (50-100) $\mathrm{nm}$ were deposited on the front surface of the silicon wafers, then indium thin film (10-30) $\mathrm{nm}$ were deposited on the front surface of the $\mathrm{ZnO} / \mathrm{n}-\mathrm{Si}$ structure as shown in figure (1).

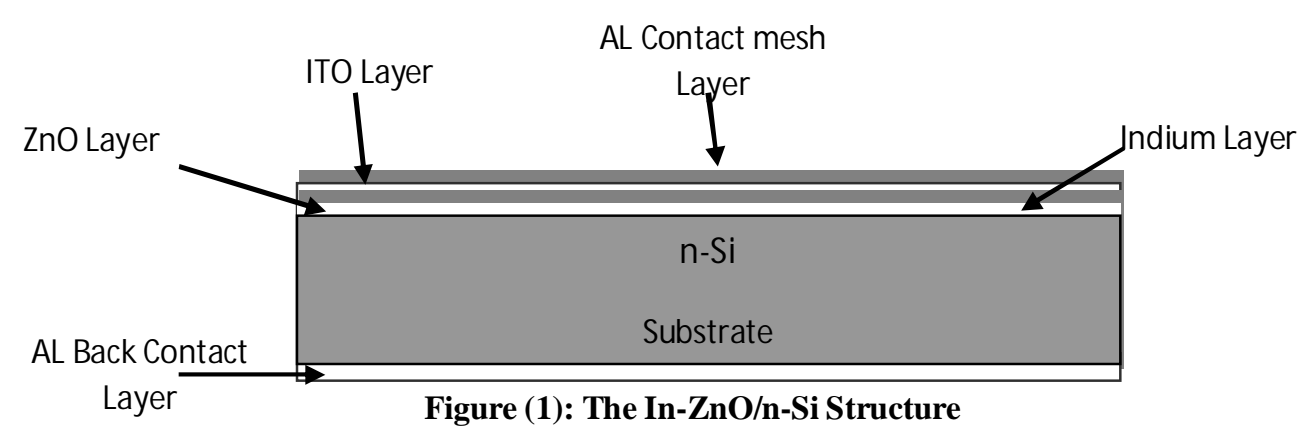


The In- $\mathrm{ZnO} / \mathrm{n}-\mathrm{Si}$ structure were annealed in the temperature range of $\left(200-500 \mathrm{C}^{\circ}\right)$ for 20 minute at pressure of $10^{-6}$ torr. A thin layer of indium tin oxide (ITO) was deposited on In- $\mathrm{ZnO} / \mathrm{n}$-Si structure to suppress oxygen diffusion from the environment, ITO is highly transparent in visible region and has high electrical conductivity and can be used as a front contact for the cell. The fabrication process steps of the $\mathrm{In}-\mathrm{ZnO} / \mathrm{n}$-si solar is shown (2).

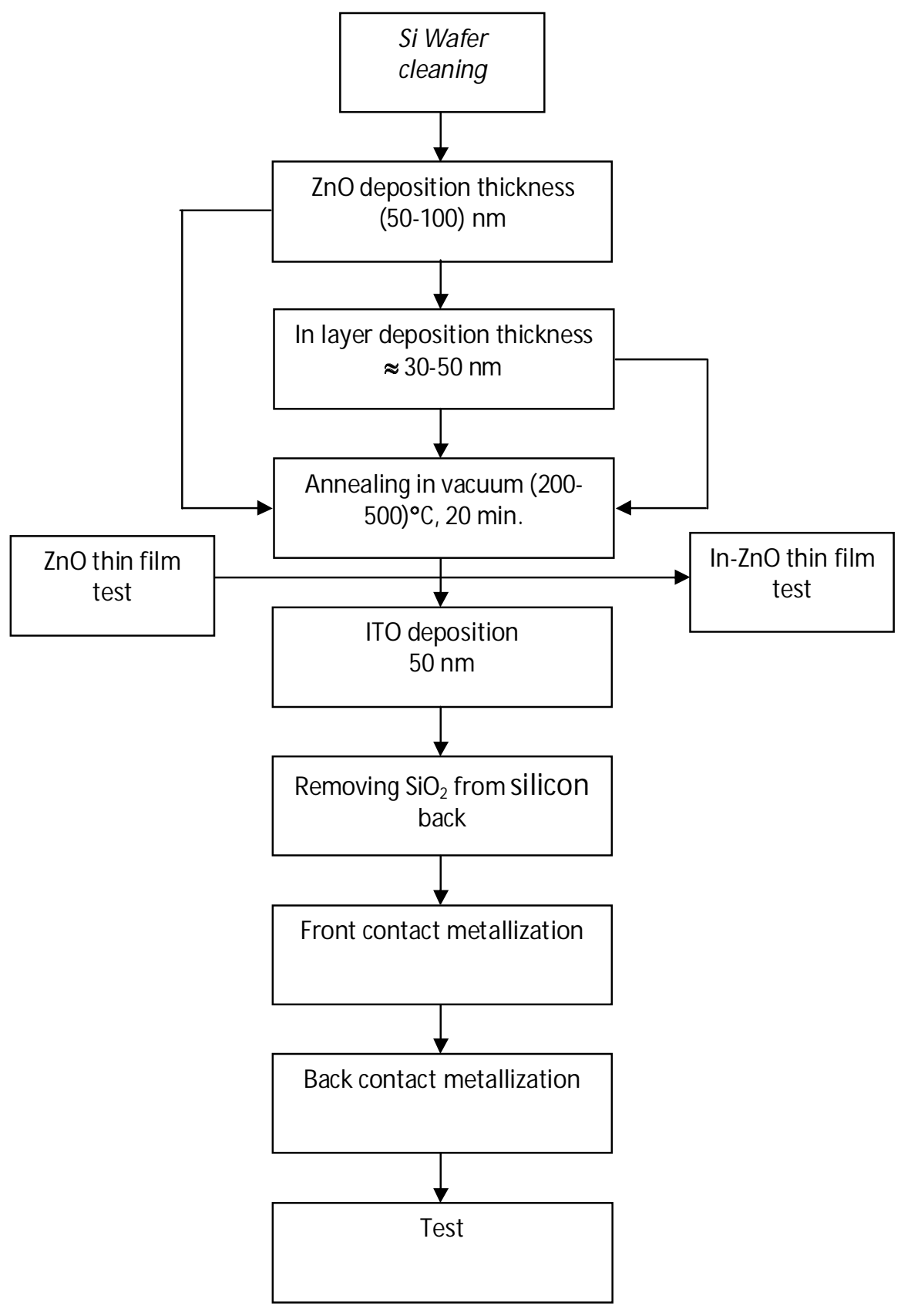

in figure

Figure.(2): The general processing for the fabricated In- $\mathrm{ZnO} / \mathrm{n}-\mathrm{Si}$ solar cells 
The back side of the samples was exposed to $10 \% \mathrm{HF}$ acid to remove the silicon dioxide layer, the back contact was formed by the deposition of Aluminum layer $(150 \mathrm{~nm})$ at the back side of the fabricated samples at $10^{-6}$ torr and annealed at $400 \mathrm{C}^{\circ}$ for an 15 minute. This heat treatment is necessary to obtain an ohmic contact between the Aluminum and the silicon wafers [6].

\section{3-Results and Discussions:}

\subsection{The transmittance spectra of $\mathrm{ZnO}$ thin films:}

In order to study the effect of $\mathrm{ZnO}$ layer thickness on the properties of the fabricated solar cell, the $\mathrm{ZnO}$ thin films were deposited on a glass slices by vacuum deposition so the optical characteristic can be studied and correlated with preparation parameters to optimize the best conditions fitting the solar cell performance. The transmittance spectra of the $\mathrm{ZnO}$ thin films were measured using a photo spectrometer as shown in figure (2).

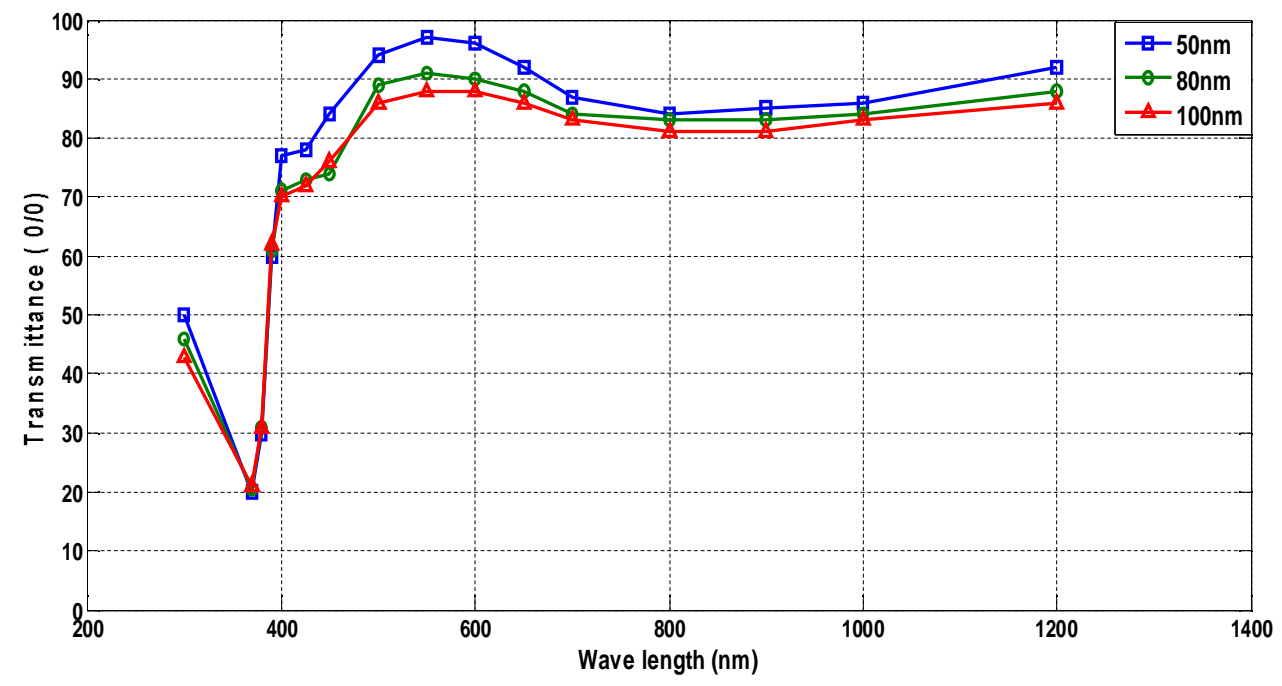

Figure. (2) The transmittance spectra of $\mathrm{ZnO}$ thin films.

It is noticed that all obtained films exhibit a high transmission $(85 \%)$ in the visible region with sharp absorption edge at $390 \mathrm{~nm}$.

The energy band gap of the $\mathrm{ZnO}$ thin films is about (3.31) $\mathrm{eV}$ and the refractive index is 1.8 as measured by the computerized photo spectrometer. The values enable the $\mathrm{ZnO}$ films acting as window and antireflection materials.

\subsection{The transmittance spectra of In-ZnO thin films:}

The optical characteristics of the In- $\mathrm{ZnO}$ thin films is also measured using a computerized photo spectrometer with different indium thickness in order to obtain the best performance of the fabricated $\mathrm{In}-\mathrm{ZnO} / \mathrm{n}-\mathrm{Si}$ solar cell. The transmission spectra of the $\mathrm{In}-\mathrm{ZnO}$ thin films is shown in Fig. (3). 


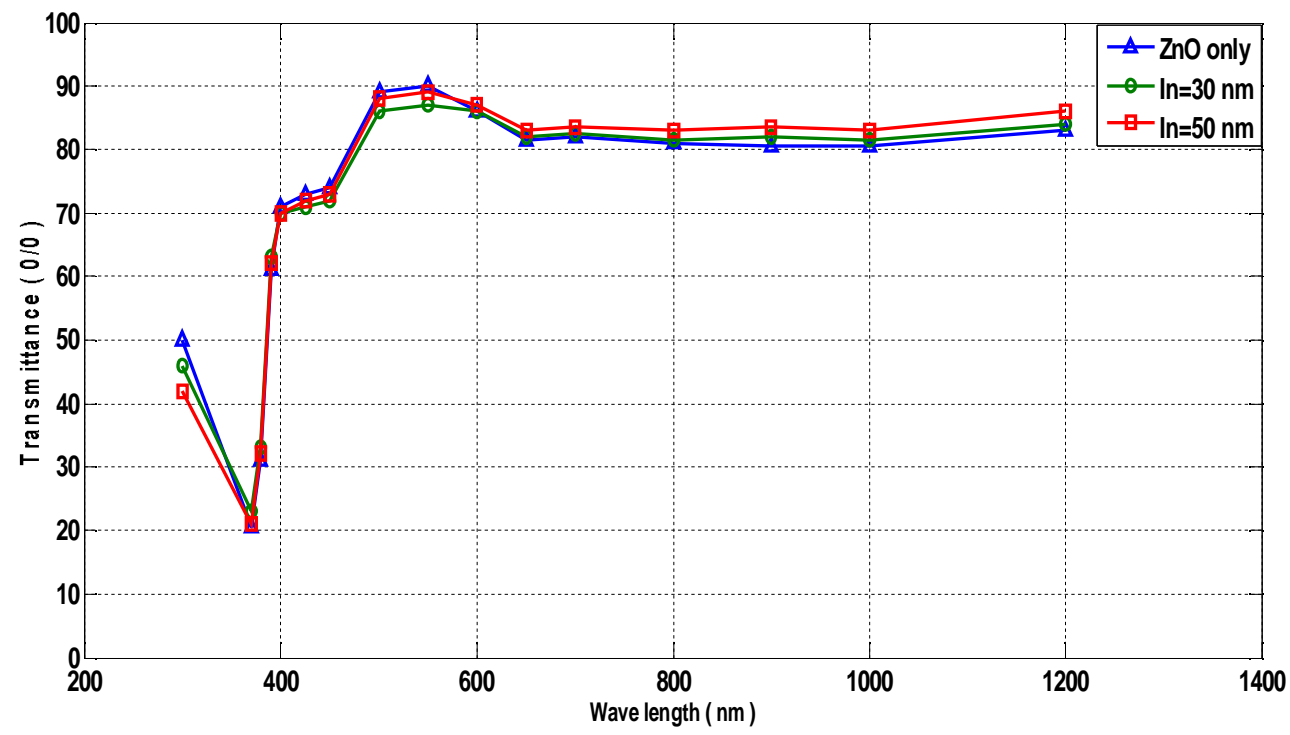

Figure. (3) The transmittance spectra of In-Zno thin films.

It is found that the In- $\mathrm{ZnO}$ films exhibit also a high transmission $83 \%$ in the visible region with sharp absorption edge at $390 \mathrm{~nm}$. The energy band gap obtained from the computerized photo spectrometer is about 3.19 and has not change much by the indium layer and the refractive index is 1.77 , this value is comparable to the value obtained from the $\mathrm{ZnO}$ thin films and enable the In- $\mathrm{ZnO}$ films acting as window and antireflection coating materials. The I-V characteristics of the. In- $\mathrm{ZnO} / \mathrm{n}-\mathrm{Si}$ samples were measured under dark and illumination condition respectively as shown in Fig. (4).

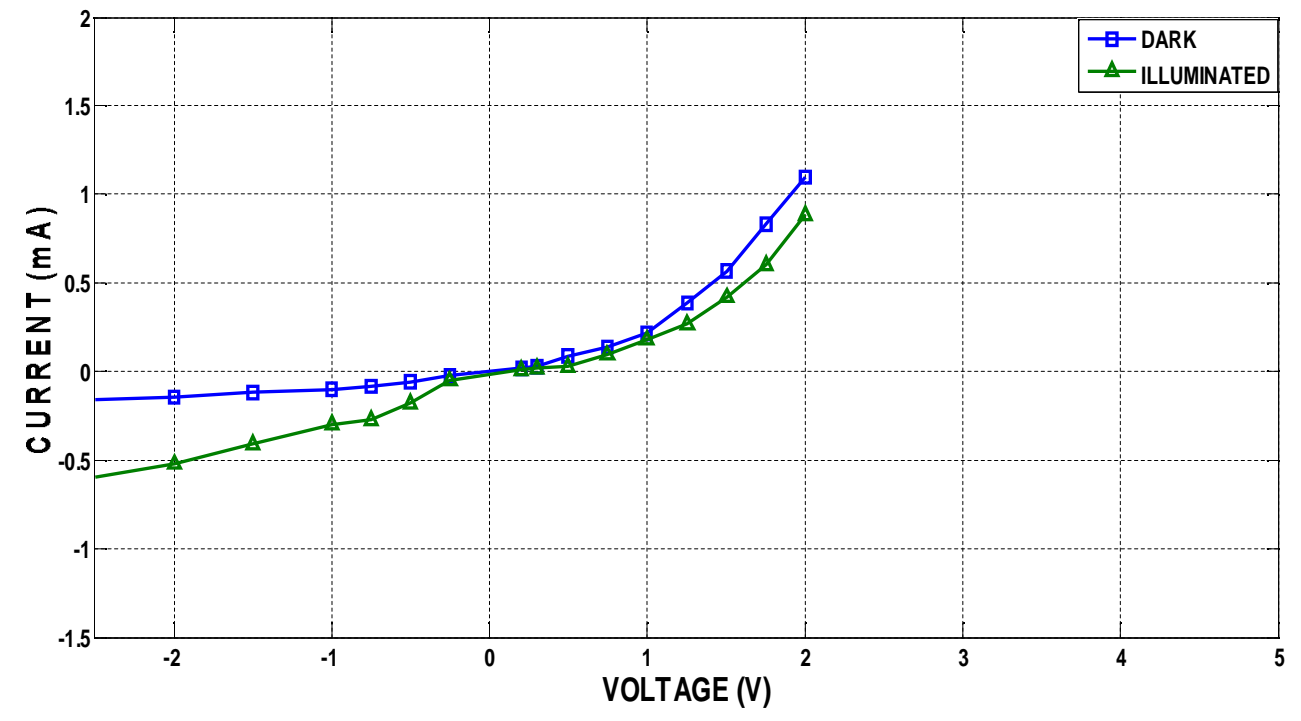

Figure (4): I-V characteristics of the In-ZnO/ $\mathrm{n}-\mathrm{Si}$ samples under dark and illumination condition . 
The forward current increases superlinearly as the applied voltage increases. When the applied voltage is reversed, the reversing current rises slowly and linearly with increasing voltage. The curve is similar to a typical $\mathrm{I}-\mathrm{V}$ characteristic of semiconductor diodes. It is noticed that the reverse current for the illuminated samples keeps about $30 \mu \mathrm{A}$ for zero applied voltage. The reverse current increases strongly for large reverse voltages and tends to be saturated at about $400 \mu \mathrm{A}$. The effect of $\mathrm{ZnO}$ layer thickness on the generated current solar cell at AM 1.5 is shown in figure Fig. (5).

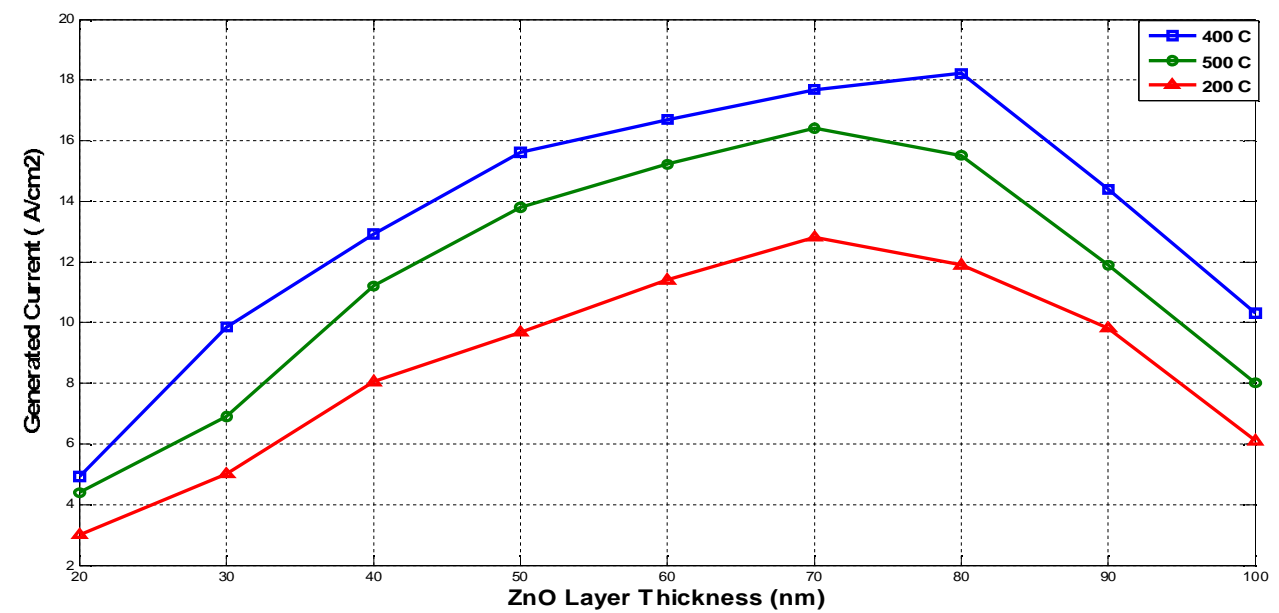

Figure (5):The effect of $\mathrm{ZnO}$ layer thickness on the generated current at AM 1.5

It is noticed that the photo generated current is increased with the increasing of $\mathrm{ZnO}$ layer thickness, the photo generated current starts decreasing gradually at $80 \mathrm{~nm}$ thickness for the sample annealed at $400 \mathrm{C}^{\circ}$, while the photo generated current for other samples starts decreasing at $70 \mathrm{~nm}$ thickness. The decreasing of the photo generated current can be attributed to the decreasing of the fill factor, the series resistance increased at large value of $\mathrm{ZnO}$ thickness layer and tend to decrease the photo generated current. Also it is clear that the annealing process of the $\mathrm{ZnO}$ layer has improve the surface roughness, and the growth condition for buffer layer is optimized to have the best characteristics at $400 \mathrm{C}^{\circ}$.

The effect of indium layer thickness on the photo generated current is shown in fig.(6).

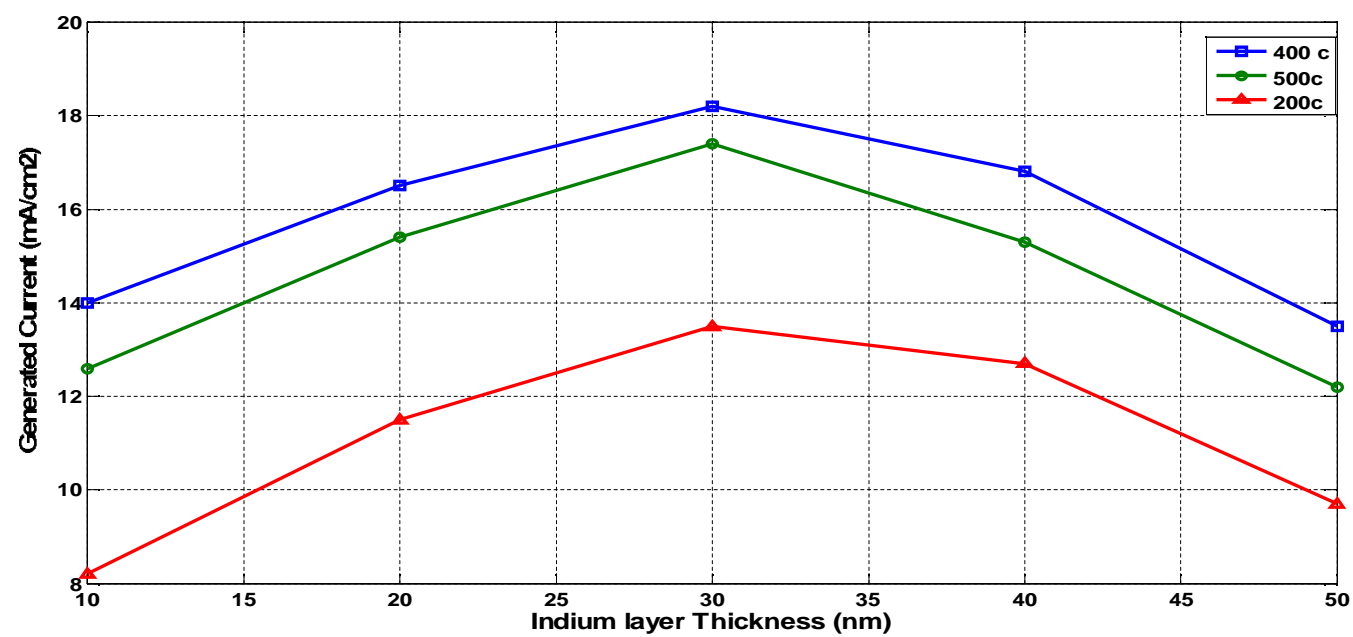

Figure (6): The effect of indium layer thickness on the 
The maximum generated current is occurred at indium thickness of about $30 \mathrm{~nm}$, at this value of thickness the band gap of InZnO layer are large enough to be transparent to most of the useful solar spectrum and the resistivity is small enough to avoid series resistance effect.

The normalized photo current response of the $\mathrm{InZnO} / \mathrm{n}-\mathrm{Si}$ solar cell at different annealing temperature and with $\mathrm{ZnO}$ layer thickness egual to $80 \mathrm{~nm}$ and indium layer thickness egual to $30 \mathrm{~nm}$ is shown in Fig. (7). The upper curve shows the photo response of In- $\mathrm{ZnO} / \mathrm{n}$-Si solar cell at $400 \mathrm{c}^{\circ}$, while the second curve is the photo response of $\mathrm{ZnO} / \mathrm{n}-\mathrm{Si}$ solar cell with out indium layer, so the indium layer has enhance the current response of the

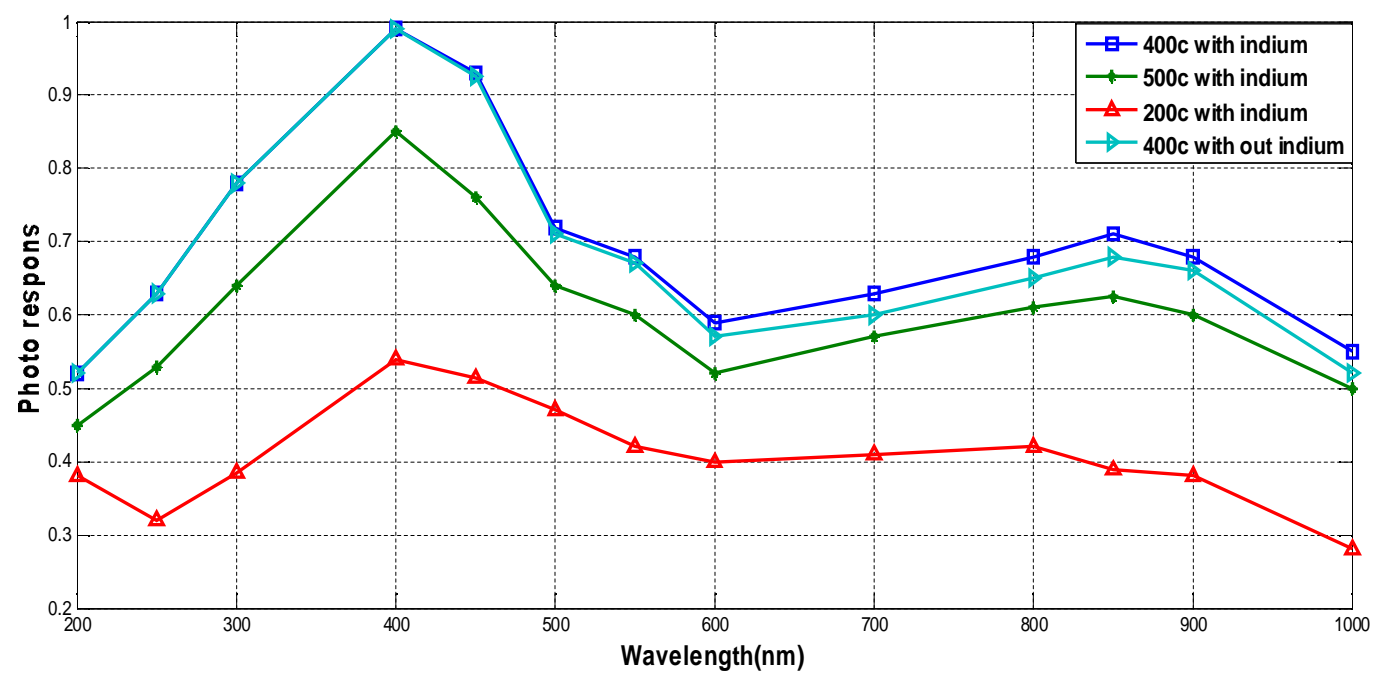

Figure (7):Normalized photo response of the In- $\mathrm{ZnO} / \mathrm{n}-\mathrm{Si}$ solar cell

fabricated samples at wavelength 500-1000 $\mathrm{nm}$.

It is clearly found that the strong photo response is shown at $390 \mathrm{~nm}$ wavelength due to the existence of $\mathrm{ZnO}$ film, the strongest response corresponds to very high energy of photons. This result indicate that a large number of photo electrons occur when the sample is illuminated by light with short wavelength. The strongest absorbing transition occurs at this levels which generates a lot of electrons in conduction band.

The photovoltaic parameter of $\mathrm{In}-\mathrm{ZnO} / \mathrm{n}-\mathrm{Si}$ solar cell is shown in the table below.

\begin{tabular}{|l|c|c|c|c|c|}
\hline \multicolumn{1}{|c|}{ Measurement Descriptions } & $\begin{array}{c}\text { V... }_{\text {OV }} \\
(\mathrm{V})\end{array}$ & $\begin{array}{c}\text { IS.C } \\
(\mathrm{mA})\end{array}$ & F.F & $\eta$ & $\begin{array}{c}\text { Barrier Voltage } \\
(\phi)(\mathrm{V})\end{array}$ \\
\hline \hline Parameter taken after fabrication. & $\mathbf{0 . 4 9}$ & 18.8 & $\mathbf{0 . 6 2}$ & 5.7 & $\mathbf{0 . 6 9}$ \\
\hline After one month. & $\mathbf{0 . 4 8 9}$ & 18.78 & $\mathbf{0 . 6 1 9}$ & $\mathbf{5 . 6 8}$ & $\mathbf{0 . 6 8}$ \\
\hline After six month. & $\mathbf{0 . 4 8 8}$ & 18.77 & $\mathbf{0 . 6 1 8}$ & $\mathbf{5 . 6 6}$ & $\mathbf{0 . 6 7 0}$ \\
\hline
\end{tabular}

It is found that the fabricated $\mathrm{In}-\mathrm{ZnO} / \mathrm{n}-\mathrm{Si}$ solar cell has an efficiency of 5.7 measured at AM 1.5, the cell output parameters stability is improved using the ITO layer at the front side of the In- $\mathrm{ZnO} / \mathrm{n}-\mathrm{Si}$ solar cell structure. The oxygen tends to diffuse through the $\mathrm{ZnO}$ layer to Si substrate allowing more degrading of cell performance. The built in potential of the solar 
cell is measured using the capacitance-voltage (CV) measurement. This CV characteristics are useful to find the donor concentration $\left(\mathrm{N}_{\mathrm{D}}\right)$, the built in potential can be estimated from the slope and the intercept of $1 / C^{2}$ versus reverse voltage. The barrier height $\phi_{\mathrm{b}}$ is related to built in potential $\mathrm{Vbi}$ by the following formula:

$$
\phi_{\mathrm{b}}=\mathrm{q} \mathrm{V}_{\mathrm{bi}}+\left(\mathrm{E}_{\mathrm{c}}-\mathrm{E}_{\mathrm{f}}\right)
$$

$\mathrm{E}_{\mathrm{c}}-\mathrm{E}_{\mathrm{f}}$ is the difference between conduction band and Fermi energy.

$$
\mathrm{E}_{\mathrm{c}}-\mathrm{E}_{\mathrm{f}}=\frac{\mathrm{KT}}{\mathrm{q}} \operatorname{In}\left(\frac{\mathrm{N}_{\mathrm{c}}}{\mathrm{N}_{\mathrm{D}}}\right)
$$

Where:

$\mathrm{Nc}=$ Effective density of states in conduction band.

$\mathrm{K}=$ Boltzmann constant.

$\mathrm{T}=$ Temperature in Kelvin.

$\mathrm{q}=$ Electronic charge.

The silicon doping concentration $\mathrm{N}_{\mathrm{D}}$ is given by:

$$
\mathrm{N}_{\mathrm{D}}=\left(\frac{2}{\mathrm{q} \varepsilon_{\mathrm{s}} \varepsilon_{\mathrm{o}} \mathrm{A}^{2}}\right)\left(\frac{\Delta_{\mathrm{V}}}{\Delta \frac{1}{\mathrm{C}^{2}}}\right)
$$

Where $\varepsilon_{\mathrm{s}}$ is the Relative permittivity of silicon., $\varepsilon_{\mathrm{o}}$ is the Permittivity of free space and A is the Solar cell area.

The barrier height can be found from the relation of built in potential and other parameter using equations (1-3) as shown in figure (8).

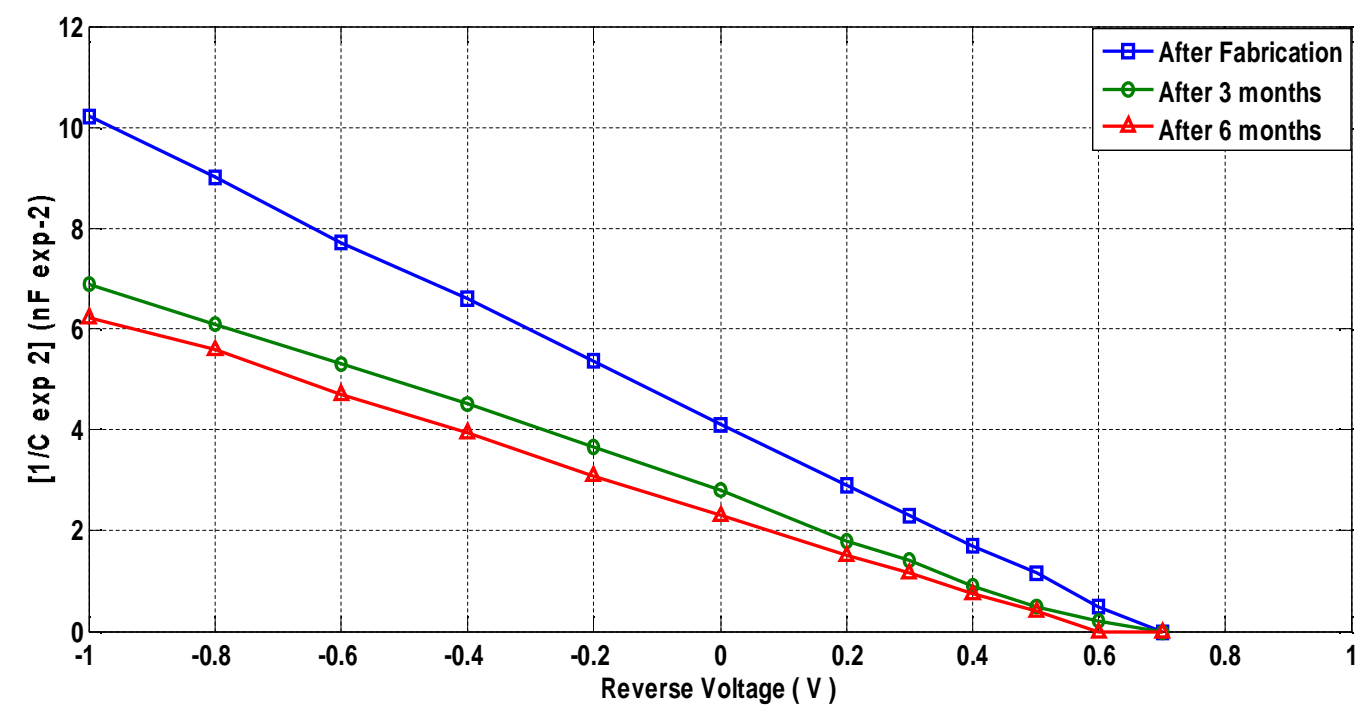

Figure (8): The plot of $1 / \mathrm{C}^{2}$ versus reverse voltage for $\mathrm{In}-\mathrm{ZnO} / \mathrm{n}$-Si solar cell. 
The decreasing of solar cell open circuit voltage $\left(\mathrm{V}_{\mathrm{O} . \mathrm{C}}\right)$ is caused by lowering the energy barrier height from 0.69 to 0.67 (after 6 month) as shown in table (1). The fabricated In$\mathrm{ZnO} / \mathrm{n}$-Si solar cell has a good performance stability, the deposition of the indium layer with the $\mathrm{ZnO}$ layer play a dominant rule for minimizing cell degradation with time as well as the indium layer tends to improve the cell efficiency beyond the visible region (700-1000) nm wavelength, the overall efficiency improvement of the fabricated solar cell is $0.4 \%$.

The degraded characteristic of $\mathrm{In}-\mathrm{ZnO} / \mathrm{n}-\mathrm{Si}$ solar cell can be also minimized by the deposition of thin oxide (ITO) layer on the front side of $\mathrm{In}-\mathrm{ZnO} / \mathrm{n}-\mathrm{Si}$ solar cell, so that the ITO layer will suppress oxygen diffusion from the environment. Also ITO is highly transparent in visible region and has small sheet resistance.

The electrical characteristics of $\mathrm{ZnO}$ layer could be enhanced by a proper doping like indium and a suitable heat treatment in order to reduce the atmospheric conditions which change the stiochiometry of $\mathrm{ZnO}$ layer or inert atmosphere at certain temperature for a certain time to minimize the imperfections and increase the crystal size which allows an increase in the generated current [7]. As well as the absorbed oxygen on the zinc oxide surface and that diffused into the bulk are evolved leaving behind a doner state which increase the free carriers [8]. It is observed that, heat treatment results in alarge reduction of In- $\mathrm{ZnO}$ film sheet resistance because of oxygen desorption from the surface pores and grain boundaries, resulting in creation of vacant sites which will act as donor states.

Figure (9) shows the effect of annealing time on the sheet resistance of $\mathrm{In}-\mathrm{ZnO} / \mathrm{n}$-si solar cell.

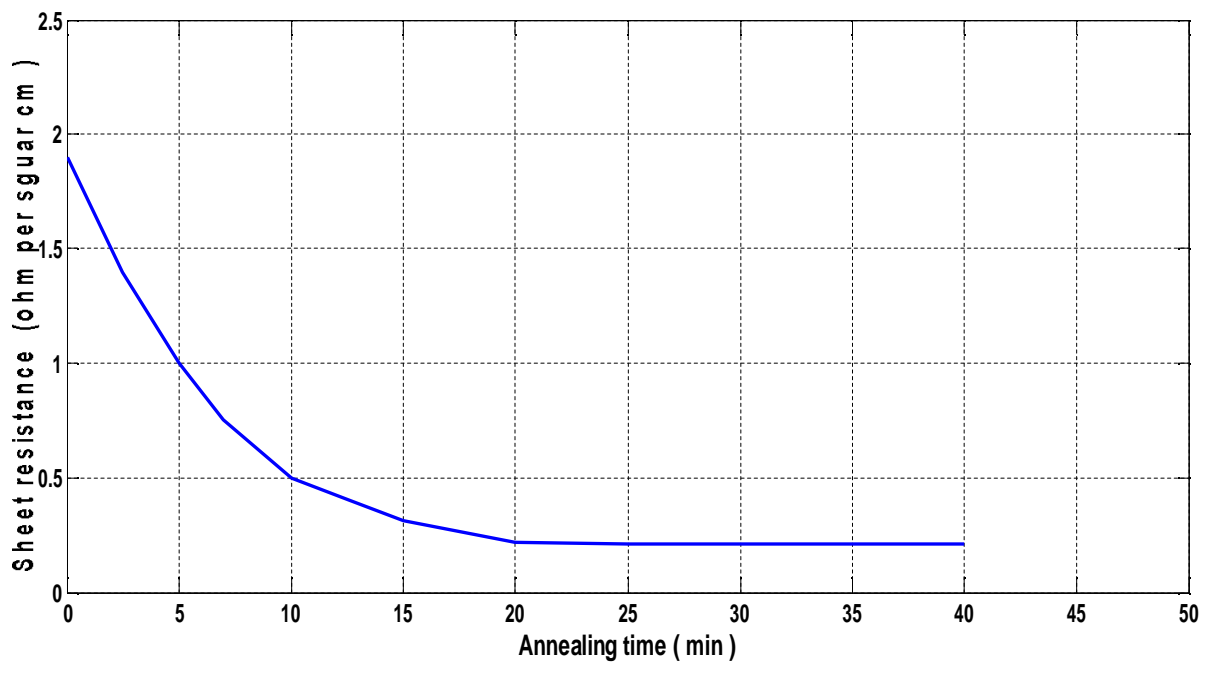

Figure.(9): The sheet resistance of $\mathrm{In}-\mathrm{ZnO} / \mathrm{n}$-Si cell at different annealing time.

It is noticed that the sheet resistance of the fabricated In-ZnO-n-si sample is reduced from $1.9 \mathrm{~K} \Omega / /\left(\Omega / \mathrm{cm}^{2}\right)$ for the as deposited film to a low value of about $211 \Omega / /$ for the annealed samples, the solar cell output parameters are improved and the stability was extended for longer time. 


\section{4-Conclusions:}

Indium-Zinc oxide/monocrystalline silicon solar cell is fabricated using vacuum evaporation technique at different annealing temperature. The electrical characteristics of $\mathrm{ZnO}$ layer was enhanced by indium doping and with suitable heat treatment resulting in reducing atmospheric conditions to change the stiochiometry of $\mathrm{ZnO}$ layer. The fabricated solar cell parameter are, $\mathrm{V}_{\mathrm{O} . \mathrm{C}}=0.48, \mathrm{I}_{\mathrm{SC}}=18.8 \mathrm{~mA}$, fill factor $=0.62$, and efficiency $\eta=5.7 \%$. the fabricated solar cell shows a good performance stability compared to the standard $\mathrm{ZnO} / \mathrm{n}-\mathrm{Si}$ solar cell. The In- $\mathrm{ZnO} / \mathrm{n}-\mathrm{Si}$ gives an efficiency improvement of about $0.4 \%$.

\section{5- References:}

5- NEAMEN, Semiconductor Physics and Devices, (C) Richard D. Irwin, INC., 1992.

6- Shewchun J. S., Singh R. and Green M. A., "Theory of Metal-InsulatorSemiconductors Solar Cells", J. Applied Physics. Vol. 48, No. 2, (USA), (1977).

7- Todorovic D. M. and Smiljanic M., "Theory of Photoacoustic Effect in MetalSemiconductor System", Institute for Chemistry, Technology and Metallurgy, Njegoseva 12, 1100. Belgrade, Yugoslavia, (2001).

8- Djoko I. and Hartano H., "Ohmic Contact Schottky Barrier", University of Indonesia, Vol. 18, pp. 74, (USA), (2004).

9- Yap Siew Hong, Carrier Transport and I-V Characteristic of Au/Si Silicodes Using Open Photo-acoustic Cell, Solid State Science and Technology. Vol. 13, No. 1 and 2, 287-295, (2005).

10- D. Derkacs, S. H. and E. T. Yu, Improved Performance of Amorphous Silicon Solar Cell Via Scattering from Surface, Applied Physics Letters 89, 093103 (2006).

11- D.G.baik,S.M. cho. Thin solid films, 354,227 .(1999)

12-Milnes A. G. and Feucht D. L., "Hetrojunction and Metal Semiconductor Junction", Academic Press, Vol. 49, pp. 133-149, (London), (1972).

9-W.F.Mohammed "Infrared Response and Guantum Efficiency of In-Doped Silicon (n) Structure" Renewable Energy 21 (2000) 323-331 .

10-H. C. Card and E. S. Yang, IEEE Trans. Electron Devices, Vol. ED-24, pp. 397, (1977).

The work was carried out at the college of Engg. University of Mosul 